\title{
Sıcaklık Stresi ile İndüklenen Broilerde Farklı Oranlarda Uygulanan Bitkisel Eksraktların Bazı Kan Parametrelerine Etkisinin İncelenmesi
}

\author{
Bülent Bayraktar ${ }^{1}$, Emre Tekce $^{2}$ \\ ${ }^{1}$ Bayburt Üniversitesi, Sağlık Bilimleri Fakültesi, Fizyoterapi ve Rehabilitasyon Bölümü, Bayburt, Türkiye \\ ${ }^{2}$ Bayburt Üniversitesi, Uygulamalı Bilimler Yüksek Okulu, Bayburt, Türkiye
}

Geliş Tarihi / Received: 19.06.2019, Kabul Tarihi / Accepted: 13.11.2019

\begin{abstract}
Özet: Sıcaklık stresi, immunosupressif etkisi nedeniyle kanatlılarda büyüme ve gelişme geriliği, metabolik problemlerden ölüme kadar varabilen sağlık sorunlarına yol açan önemli bir stres etmenidir. Bu çalışma, sıcaklık stresine maruz kalan kanatlılarda bitkisel ekstrakt kullanımına bağlı olarak serumda P düzeylerinin karşılaştırılmasının yanı sıra eş zamanlı olacak şekilde içme sularına ilave edilen stresin etkisini azaltılmasında antioksidan özelliklere sahip Eucalyptus glabutus labii (ökaliptus), Tymus vulgaris (kekik),Cymbopogon nardus (sitronella) ve Syzgium aromaticum (karanfil) bitkilerinden oluşan uçucu yağ karışımının (EOM) bazı kan parametreleri (Fosfor (P), Lipaz, Sodyum (Na), Klor (Cl), Doymamış demir bağlama kapasitesi (UBİC), Total Demir Bağlama Kapasitesi (TIBC), Transferin Doygunluğu (\% SAT) düzeyi üzerine olan etkisi araştırılmıştır. Araştırmada her birinde 50 adet hayvan olacak şekilde 8 gruba ayrılmıştır. Gruplar kendi içerisinde her bölmede 10 adet hayvan olacak şekilde 5 alt grubu içermektedir. UIBC ve TIBC düzeyleri kontrol grubuna kıyasla $22^{\circ} \mathrm{C}$ gruplarda $500 \mathrm{ml} / 10001$ gruplarda en fazla artı̧ gözlenirken, $36^{\circ} \mathrm{C}$ gruplarda ise $500 \mathrm{ml} / 10001$ gruplarda en fazla azalma tespit edilmiştir $(p<0,05)$.Deney sonucunda gruplara ait veriler incelendiğinde sıcaklık stresine maruz kalan broylerin içme suyuna ilave edilen EOM'un serumda P, Lipaz, Na, \% SAT düzeyleri üzerinde önemli bir etkisinin olmadığı tespit edilmiştir $(\mathrm{p}>0,05)$.
\end{abstract}

Anahtar kelimeler: Bitki eksraktı, broyler, kan parametreleri, sıcaklık stresi

\section{Investigation of the Effect of Vegetable Exracts on Some Blood Parameters in Broiler Exposed by Heat Stress}

\begin{abstract}
Heat stress, growth and developmental retardation in poultry due to its immunosuppressive effect is an important stress factor leading to health problems ranging from metabolic problems to death. In this study, we compared the phosphorus levels in serum due to the use of herbal extracts in poultry subjected to temperature stress, as well as the effect of the stress added to drinking water simultaneously on the effect of antioxidant properties Eucalyptus glabutus labii (eucalyptus), Tymus vulgaris (thyme), Cymbopogon nardus (citronella) ve Syzgium aromaticum (clove) (EOM) of some blood parameters (phosphorus (P), lipase, Sodium (Na), Chlorine $(\mathrm{Cl})$, Unsaturated Iron Binding Capacity (UBIC), Total Iron Binding Capacity (TIBC), Transfer Saturation (\% SAT)) the effect on the level of was investigated. The study was divided into 8 groups with 50 animals each. The groups consist of 5 sub-groups with 10 animals in each compartment. In the $22^{\circ} \mathrm{C}$ groups, there was an increase in UBIC and TIBC parameters in the groups given EOM mixture compared to the control group, while the maximum increase was seen in $500 \mathrm{ml} / 10001$ groups. UIBC and TIBC levels were the highest increase in the $500 \mathrm{ml} / 10001$ groups in the $22{ }^{\circ} \mathrm{C}$ groups compared to the control group, while the highest decrease was observed in the $500 \mathrm{ml} / 10001$ groups in the $36^{\circ} \mathrm{C}$ groups $(\mathrm{p}<0,05)$. At the end of the experiment, it was found that EOM added to drinking water of brolier exposed to heat stress did not have a significant effect on serum P, Lipase, Na, \% SAT levels ( $\mathrm{p}>0,05)$.
\end{abstract}

Key words: Blood parameters, broiler, heat stress, plant extract

\section{Giriş}

Kanatl1larda önemli bir stres etmeni olan sıcaklık stresi, fizyolojik, hormonal, davranışsal değişikliklere yol açan immunosupressif etkisi nedeniyle büyümede yavaşlama ve mortalite oranında artışa yol açmaktadır (Al-Marzooqi ve Leeson 1999; AOAC 2005; Abdulkarimi ve Daneshyar 2012).Bu etkileri nedeniyle ekonomik olarak kanatlı sektörünün başlıca önemli sorunları arasında yer almaktadır.

Stres, biyokimyasal parametrelerin değişmesinde önemli bir etmendir (Al-Marzooqi ve Leeson 1999).Fosfor, büyüme-gelişmeden, kemik formasyonu, hormon aktivasyonu, hücre metabolizmas1 ve hücreler arası sinyal iletimi, asit-baz dengesine 
kadar pek çok fizyolojik süreçte önemli rolü bulunan, bütün hayvan türleri için esansiyel ve yaşam için vazgeçilmez bir öneme sahip bir elementtir (Asimov 1974; Moraesa ve ark. 2003). Sicaklik stresine bağli olarak Broyler civciv ve tavuklarda, plazma inorganik fosfat seviyelerinin azaldığı bildirilmektedir (Borges ve ark. 2004; Conway ve ark. 2006). Ancak, broylerde sicaklık stresi indüklenmesi ve bitkisel ekstrakt uygulamasına bağlı olarak serum P düzeyinin değişimine yönelik kısıtlı sayıda çalışma bulunmaktadır. Plazmadaki P düzeyi, diyetle alınan P miktarı, hayvan türü, yaş, gibi birçok fizyolojik etmene bağlı olarak değişkenlik göstermekte ve serumdaki normal düzeyi $2,5-4,5 \mathrm{mg} / \mathrm{dl}$ aralığında değişkenlik göstermektedir. Bu oran 1,5 $\mathrm{mg} / \mathrm{dl}$ altına düşmesi halinde ölüm riski artmaktadır (Nelson, 1967; Conway ve ark. 2006; Daneshyar ve ark. 2009). Ayrıca, hızla büyüme ve gelişme sürecindeki genç civcivler P eksikliğine așırı duyarlılık göstermektedir. Bu nedenle, P'nın ideal değerlerinin bilinmesi, korunması ve takip edilmesi önem arz etmektedir. Fizyolojik açıdan bitkisel kaynaklarda bulunan P'nın fitik asit formunda bulunması nedeniyle kanatlılarda P'nın yararlanma derecesi oldukça düşük düzeydedir (NRC 1984; Conway ve ark. 2006). Kanatlı rasyonlarında $\mathrm{P}$ elementinin yetersizliği ve plazmadaki $P$ düzeyi düşüklüğü, yumurta verimi ve kalitesinde de azalma, büyüme performansında gerileme gibi verim performanslarını olumsuz etkilenmesinin yanı sıra pika, yağlı karaciğer, metabolik bozukluklar, raşitizm gibi genel durum bozukluklarından ölüm olgusuna kadar varabilen önemli bir sağlik sorunlarına yol açmaktadır (Al-Marzooqi ve Leeson 1999).Diğer yandan, kanatlı rasyonlarında kullanılan $\mathrm{P}$ ve Ca miktarında hafif sapmaların ani ölüm görülme insidansını arttırılabilmesi açısından da kanatlı besleme programlarında kritik bir öneme sahiptir (Al-Marzooqi ve Leeson 1999; Dorman ve Dean 2000). Lipaz, pankreastan salgilanan ve yaklaşık 42 Kilodalton $(\mathrm{kDa})$ moleküler ağırlığında trigliseridleri 1 . ve 3 . pozisyonlarında hidrolize ederek geride monogliserid birakan pankreatik hastalıkların tanısında kullanılan bir sindirim enzimidir. Pankreas dokusunda meydana gelen türlü zedelenme serum lipaz aktivitesinde yükselmeye sebep olmaktadır (González 2006).

Kanatlilarda, pankreas fonksiyonun değerlendirmesinde serum amilaz ve lipaz konsantrasyonları ölçülmektedir. Bu parametrelerdeki meydana gelen artış, pankreas veya böbrek hasarı ile ilişkili değerlendirilmektedir (ICSH 1978; Isolauri ve ark. 2001). Serum demir düzeyi, hemoglobin ( $\mathrm{Hb}$ ) sentezi için gerekli demiri miktarının belirlenmesinde, TIBC ise anemilerin ve demir metabolizmasının değerlendirilmesinde, UBİC ve \% SAT parametreleri ise doymamış demir bağlama kapasitesinin hesaplanmasında kullanılmaktadır. Serumda \% SAT düzeyi, serum transferrin konsantrasyonunun doğrudan göstergesi olan toplam demir bağlama kapasitesiyle (TIBC) ters orant1 göstermektedir (Kefalı ve Toker 2006). Biyokimyasal parametrelerin değişmesine yol açan stresin kanatlılarda olası zararlı etkilerinin azaltılabilmesine yönelik araştırmalar durduraksız devam etmektedir. Kanatlilarda stres sonucu meydana gelen ölüm ve enfeksiyonların azaltılması, verimliliğin arttırılmasında başta bazı antimikrobiyal, antioksidan etkilere sahip bitki ekstraktı, probiyotikler, prebiyotiklerin kullanılması önemli uygulamalar içerisinde yer almaktadır (Klasing 1998; Khan ve ark. 2002; Botsoglou ve ark. 2004). Gerçekleştirilen bu deneysel çalışma, sıcaklık stresi ile indüklenen broylerde serumda P, lipaz, Na, Cl, P, UBİC, TIBC, $\%$ SAT düzeylerinin karşılaştırılmasının yanında eş zamanlı olarak içme sularına ilave edilen stresin olumsuz etkilerinin azaltılmasına yardımcı olan antioksidan özelliklere sahip EOM serumda P, lipaz, $\mathrm{Na}, \mathrm{Cl}$, UBİC, TIBC, \% SAT düzeyleri üzerindeki etkisinin incelemesi amacıyla yapılmıştır.

\section{Gereç ve Yöntem}

\section{Hayvan Materyali}

Araştırma için hayvan materyali olarak 400 adet bir günlük yaştaki Ross-308 etlik civciv kullanıldı. Çalışma, alıştırma ( 7 gün) ve besi (35 gün) dönemlerini kapsayacak şeklinde toplam 42 gün sürdü. Her grupta 50 hayvan olacak şekilde 8 farklı gruba ayrıld1. Her grupta kendi içerisinde her bölmede 10 adet hayvan olacak şekilde $23^{\circ} \mathrm{C}$ stressiz grup ve $36^{\circ} \mathrm{C}$ stres uygulanacak şekilde Kontrol (K), K+250 $\mathrm{ml} / 1, \mathrm{~K}+500 \mathrm{ml} / \mathrm{L}, \mathrm{K}+750 \mathrm{ml} / \mathrm{L}$ olacak 5 alt gruba ayrıldı. Çalışma etik kurul onayını takiben (Karar tarihi ve say1s1: 22.02.2018-2/24), Bayburt Üniversitesi G1da, Tarım ve Hayvancılık Uygulama ve Araştırma Merkezi Birimine bağlı kanatlı ünitesinde, hayvan refahı ve hakları korunarak etik ilke ve kurallarına riayet edilerek gerçekleştirildi. Araştırma süresince 
broyler civcivlerin önünde sürekli olarak günlük ve taze su bulunduruldu. Deneme kümesinin genel 1sıs1 ilk 2 gün $32-33^{\circ} \mathrm{C}$ ve daha sonraki 5 günde $27-28^{\circ} \mathrm{C}^{\prime}$ de sabit tutulmuş daha sonra kademeli olarak artırılarak sıcaklık stresi uygulandığı dönemde sicaklık $36^{\circ} \mathrm{C}$ 'de nem ise \% 75-85, 1s1 stresi uygulanmayan gruplar ise $22^{\circ} \mathrm{C}$ 'de sicaklik sabit tutulmuştur. Deneme boyunca 24 saat aydınlık (60 W) olacak şekilde uygulandı. Tüm gruplara tablo 1'de içeriği verilen bazal diyet yemleri verildi. İçme suları da her gün aynı saatte alınarak içlerine EOM ilave edilerek yeni suları hayvanlara verildi. $\mathrm{Bu}$ araştırma için kullanılan yemlerin analizi, A.O.A.C belirtilen yöntemlere uygun olarak gerçekleştirildi (AOAC 2005).

Tablo 1: Temel rasyonun kompozisyonu ve bileşimi (\%)

\begin{tabular}{lccc}
\hline Ham maddeler & Başlangıç yemi (0-14 gün) & Büyütme yemi (14-28 gün) & Bitiriş yemi (28-42 gün) \\
\hline Mısır & 52,70 & 54,60 & 58,12 \\
Mısır Gluten Yemi & 15,21 & 21,20 & 26,14 \\
Soya Fasulyesi Küspesi & 26,35 & 18,90 & 10,65 \\
Di-kalsiyum Fosfat & 1,95 & 1,70 & 1,60 \\
Kalsiyum Karbonat & 1,18 & 1,10 & 1,04 \\
Sodyum Klorür & 0,31 & 0,31 & 0,31 \\
Sodyum Bikarbonat & 0,20 & 0,20 & 0,20 \\
Tuz & 0,20 & 0,20 & 0,20 \\
Metiyonin & 0,50 & 0,50 & 0,44 \\
Lizin & 1,20 & 1,10 & 1,10 \\
Vitamin- mineral premiks & 0,20 & 0,20 & 0,20 \\
\hline ME (Kcal/ kg) & 3100 & 3150 & 3225 \\
Ham Protein \% & 24 & 22 & 20 \\
Ham Yağ \% & 2,61 & 2,30 & 2,50 \\
Nem \% & 13,20 & 13,20 & 13,20 \\
\hline
\end{tabular}

EOM Karışımın İçeriği

EOM karışımına ait içerik Bayburt Üniversitesi Merkez Araştırma Laboratuvarlarında GC (Gaz kromatografisi) (Agilent 5977B, GC/MSD, GERMANY) cihazı ile analiz ettirilmiştir (Özek ve ark. 2010). EOM içeriğinde \%26,70 Durenol, $\% 23,89$ Öcenol, \%16,49 Gamma terpinen, \%8,35 Heptaetilen glikol, \%6,42 Heksaetilen glikol, \%3,31 simen, \%3,08 Penetilen glikol, \%2,87 Kariofilen, $\% 2,30$ D-Limonen, \%2,18 Betapinen, \%0,95 Ökaliptol bulunmuştur.

\section{Kan Örneklerinin Toplanması}

Araştırma sonucunda, her grup içerisinden rastgele bir şekilde 10 ve toplamda 80 hayvan kesim sırasında akan kandan örnekler alındı. Kan numunelerinde serum elde edilmesi için soğutmalı santrifüjde (NF 1200R, NÜVE, Ankara, TÜRKIYE) 12 dakika santrifüj edildi.

\section{Serum P, lipaz, Na, CI, \% SAT, UBİC, TIBC} Tayini

Serumda P düzeyi, Cobas-8000 otoanalizörde (Roche Diagnostics, Almanya) ölçümü gerçekleştirilmiştir. Serum transferrin doygunluk seviyeleri, aşağıdaki formülasyonla serum demir düzeyleri ve serum toplam demir bağlama kapasitesi seviyelerinden hesaplanarak belirlendi Voyvoda ve ark. (1992): Transferrin doygunluğu $(\%)=(\mathrm{Fe} / \mathrm{TIBC}) \times 100$

\section{İstatistiksel analiz}

Araştırma verilerinin istatiksel analizinde IBM SPSS 20.0 programinda stresin rasyonlara katılan ekstrakt, stres ve diyet*stres faktörleri üzerine etkileri General Linear Model Univariate'de Duncan testi uygulanmıştır. Verilerin ortalamaları standart hatalarıyla ifade edilerek $( \pm)$ anlamlı farklılıklar 
$\mathrm{p}<0,05$ düzeyinde test edilip değerlendirilerek incelenmiştir.

\section{Bulgular}

Deneysel olarak sicaklık stresi ile indüklenen broyler gruplarında içme suyuna ilave edilen EOM karışımına bağlı olarak bazı kan parametreleri üzerine etkisinin belirlenmesi amaciyla elde edilen veriler (Tablo 2) aşağıda tablo halinde verilmiştir. Tüm gruplarda uygulanan broyler gruplarında $22^{\circ} \mathrm{C}$ gruplarda serumda UIBC ve TIBC parametreleri üzerine kontrol grubuna kıyasla EOM karışımı verilen gruplarda artış olurken en fazla artışın 500 $\mathrm{ml} / 1000 \mathrm{~L}$ gruplarda görülmüştür. $36^{\circ} \mathrm{C}$ gruplarda ise UIBC, TIBC ve $\mathrm{Cl}$ parametreleri üzerine kontrol grubuna kıyasla azalma olduğu en fazla azalmanın da $500 \mathrm{ml} / 1000 \mathrm{~L}$ gruplarda olduğu tespit edilmiştir $(p<0,05)$. Diğer yandan her iki deney grubunda uygulanan EOM karışımı uygulaması neticesinde $\mathrm{P}$, lipaz, \% SAT, Na düzeyleri üzerine etkisi olmamış$\operatorname{tir}(\mathrm{p}>0,05)$.

Tablo 2. Sicaklık stresi uygulanan deney gruplarında EOM uygulamasının bazı kan parametrelerine göre interaksiyonu.

\begin{tabular}{|c|c|c|c|c|c|c|c|c|c|c|c|c|c|c|}
\hline & \multicolumn{2}{|c|}{ UIBC } & \multicolumn{2}{|c|}{ TIBC } & \multicolumn{2}{|c|}{ SAT $\%$} & \multicolumn{2}{|c|}{ Lipaz } & \multicolumn{2}{|c|}{$\mathbf{N a}$} & \multicolumn{2}{|c|}{$\mathbf{C l}$} & \multicolumn{2}{|c|}{$\mathbf{P}$} \\
\hline & $22^{\circ} \mathrm{C}$ & $36^{\circ} \mathrm{C}$ & $22^{\circ} \mathrm{C}$ & $36^{\circ} \mathrm{C}$ & $22^{\circ} \mathrm{C}$ & $36^{\circ} \mathrm{C}$ & $22^{\circ} \mathrm{C}$ & $36^{\circ} \mathrm{C}$ & $22^{\circ} \mathrm{C}$ & $36^{\circ} \mathrm{C}$ & $22^{\circ} \mathrm{C}$ & $36^{\circ} \mathrm{C}$ & $22^{\circ} \mathrm{C}$ & $36^{\circ} \mathrm{C}$ \\
\hline Kontrol & $0,00^{\mathrm{b}}$ & $22,40^{\mathrm{a}}$ & $88,20^{\mathrm{b}}$ & $110,40^{\mathrm{a}}$ & 7115,83 & 9686,87 & 0,00 & 0,00 & 148,20 & 147,60 & 114,00 & $116,80^{\mathrm{a}}$ & 5,92 & 5,68 \\
\hline EOM 250 ml/10001 & $20,60^{\mathrm{ab}}$ & $17,80^{\mathrm{ab}}$ & $102,80^{\mathrm{ab}}$ & $96,00^{\mathrm{ab}}$ & 8508,20 & 7709,72 & 0,00 & 0,00 & 150,80 & 146,60 & 116,40 & $115,40^{\mathrm{a}}$ & 5,44 & 5,82 \\
\hline EOM 500 ml/10001 & $25,20^{\mathrm{a}}$ & $3,80^{c}$ & $128,60^{\mathrm{a}}$ & $79,80^{\mathrm{b}}$ & 11314,18 & 7480,85 & 0,00 & 0,00 & 150,00 & 137,40 & 115,20 & $104,00^{\mathrm{b}}$ & 5,76 & 6,66 \\
\hline EOM 750 ml/10001 & $18,60^{\mathrm{ab}}$ & $9,00^{\mathrm{bc}}$ & $117,00^{\mathrm{ab}}$ & $94,00^{\mathrm{ab}}$ & 10844,31 & 12065,46 & 0,00 & 0,00 & 149,00 & 149,40 & 112,60 & $115,80^{\mathrm{a}}$ & 7,08 & 4,74 \\
\hline \multicolumn{15}{|c|}{ Varyasyon kaynağı (P değerleri) } \\
\hline Diyet & \multicolumn{2}{|c|}{0,52} & \multicolumn{2}{|c|}{0,86} & \multicolumn{2}{|c|}{0,41} & 0,00 & 0,00 & \multicolumn{2}{|c|}{0,30} & \multicolumn{2}{|c|}{0,07} & \multicolumn{2}{|c|}{0,82} \\
\hline Sicaklik & \multicolumn{2}{|c|}{0,46} & \multicolumn{2}{|c|}{0,03} & \multicolumn{2}{|c|}{0,89} & 0,00 & 0,00 & \multicolumn{2}{|c|}{0,06} & \multicolumn{2}{|c|}{0,39} & \multicolumn{2}{|c|}{0,47} \\
\hline Sicaklık*Diyet & \multicolumn{2}{|c|}{0,00} & 0,0 & & \multicolumn{2}{|c|}{0,49} & 0,00 & 0,00 & \multicolumn{2}{|c|}{0,17} & \multicolumn{2}{|c|}{0,03} & \multicolumn{2}{|c|}{0,07} \\
\hline \multicolumn{15}{|c|}{ Diyetin başlıca etkisi } \\
\hline Kontrol & \multicolumn{2}{|c|}{$11,20 \pm 3,81$} & \multicolumn{2}{|c|}{$99,30 \pm 6,45$} & \multicolumn{2}{|c|}{$8401,35 \pm 1536,86$} & 0,00 & 0,00 & \multicolumn{2}{|c|}{$147,90 \pm 2,23$} & \multicolumn{2}{|c|}{$115,40 \pm 1,80^{\mathrm{a}}$} & \multicolumn{2}{|c|}{$5,80 \pm 0,44$} \\
\hline EOM 250 ml/10001 & 19,20 & $\pm 3,81$ & $99,40=$ & $\pm 6,45$ & $8108,96 \pm$ & $\pm 1536,86$ & 0,00 & 0,00 & 148,70 & $\pm 2,23$ & 115,90 & $\pm 1,80^{\mathrm{a}}$ & $5,63 \pm$ & $=0,44$ \\
\hline EOM 500 ml/10001 & 14,50 & $\pm 3,81$ & 104,20 & $\pm 6,45$ & $9397,52 \pm$ & $\pm 1536,86$ & 0,00 & 0,00 & 143,70 & $\pm 2,23$ & 109,60 & $\pm 1,80^{\mathrm{b}}$ & $6,21 \pm$ & 0,44 \\
\hline EOM 750 ml/10001 & 13,80 & $\pm 3,81$ & 105,50 & $\pm 6,45$ & 11454,88 & $\pm 1536,86$ & 0,00 & 0,00 & 149,20 & $\pm 2,23$ & 114,20 & $\pm 1,80^{\mathrm{ab}}$ & $5,91 \pm$ & $=0,44$ \\
\hline & & & & & & icaklık & & & & & & & & \\
\hline $22{ }^{\circ} \mathrm{C}$ & 16 , & 100 & 109, & 150 & 9445 & 5,636 & 0,00 & 0,00 & 149 , & 500 & 114 &, 550 & 6,0 & 50 \\
\hline $36^{\circ} \mathrm{C}$ & 13,2 & 250 & 95,0 & 50 & 9235 & 5,728 & 0,00 & 0,00 & 145 , & 250 & 113 &, 000 & 5,7 & 25 \\
\hline SEM & 2, & 70 & 4,5 & & 108 & 6,72 & 0,00 & 0,00 & 1, & 57 & & 27 & 0,3 & 31 \\
\hline
\end{tabular}

\section{Tartışma ve Sonuç}

Sicaklık stresi, kanatlılarda K, Na, Ca gibi minerallerin atılımını arttırarak, $\mathrm{Mg}$ ve dolayısıyla kuşların elektrolit dengesini bozmaktadır (McCormick ve ark. 1979; Molero 2007). Başta P, Ca, Na, Mg gibi elementlerin seviyelerinin azalmasına yol açmaktadir (Kohne ve Jones 1975; Klasing 1998). Ayrıca, akut sıcaklık stresine maruz kalarak aç bırakılmış tavukların hayatta kalmasını etkileyen elementlerden birisi olan $\mathrm{P}$ ve $\mathrm{Ca}$ bu açıdan da kritik bir öneme sahip olduğu bildirilmektedir (Smith ve Teeter 1987;Savica ve ark. 2012).

Mevcut çalışmamız için gerçekleştirilen literatür taramasında sicaklık stresine maruz kalan broyler içme suyuna farklı oranlarda EOM uygulamasının serumda P, lipaz, Na, Cl, UBİC, TIBC, \% SAT 
seviyelerinin nasıl değiştirdiğine yönelik çalışmalar kısıtlı sayıda bulunmaktadır. Ayrıca, mevcut çalışma sicaklık stresi uygulanan etlik piliçlerde içme sularına farklı oranlarda katılan bitkisel ekstraktların bazı biyokimyasal parametreler üzerindeki etkisinin incelenebilmesine olanak sağlaması yönünden önemlilik arz etmektedir. Araştırma sonucunda EOM uygulamasına bağlı olarak serumda P, lipaz, UBİC, TIBC, Na, \% SAT değerleri üzerinde etkisi bulunmadığı tespit edilmiştir. Elde edilen veriler yapılan araştırma sonuçlarıyla uyumluluk göstermektedir (Nelson, 1967; McCormick ve ark. 1980; Vahl ve ark. 1987; Lumeij 1997; Salvador ve ark. 1999; Borges ve ark. 2004; Khan ve ark. 2002; Daneshyar ve ark. 2009; Tekce ve Gül 2015). TIBC, transferrinin gerçek demir bağlama kapasitesini, demir emiliminin ve tahmini bilgi sağlayan önemli bir göstergedir (ICSH 1978; Daneshyar ve ark. 2009).İçme suyuna ilavesine kekik eksraktı uygulandığ 1 araştırmada serumda TIBC miktarı anlamlı bir farklılık gözlenmediği bildirilmiştir. Mevcut araştırmamızın sonuçlarıyla uyumluluk göstermektedir (Conway ve ark. 2006).

Sonuç olarak mevcut çalışmamızda EOM uygulamasına bağlı olarak serumda P, lipaz, UBİC, TIBC, Na, \% SAT değerleri üzerinde etkisinin bulunmamasının nedeni araştırma sürecince 1sı uygulamasına karşı vücudun termoregülasyon mekanizmalarında epigenetik adaptasyon kazanabilmiş olabileceği kanaatine varılmıştır. Mevcut çalışmaların kısıtlı sayıda olması nedeniyle daha kapsamlı araştırmalar yapılmasına ihtiyaç duyulmaktadır.

\section{Teșekkür}

$\mathrm{Bu}$ çalışma içerisinde yer alan lipaz parametresi, 25-27 May1s 2018 tarihlerinde 1.Uluslararası GAP Tarım ve Hayvancılık Kongresinde "Investigation of the Effect of Some Plant Extracts on Serum Lipase Used in Drinking Waters at Different Rates in Heat Stress Induced Broilers" başlıkla sözlü bildiri olarak sunulmuştur.

\section{Kaynaklar}

1. Abdulkarimi R, Daneshyar M. (2012) The effects of thyme (Thymus vulgaris) extract supplementation in drinking water on iron metabolism in broiler chickens. J Med Plant Res. 6(5),645-650. DOI: 10.5897/JMPR11.090.
2. Al-Marzooqi W, Leeson S. (1999) Evaluation of dietary supplements of lipase, detergent, and crude porcine pancreas on fat utilization by young broiler chicks. Poult Sci. 78(11), 1561-1566. DOI:10.1093/ps/78.11.1561.

3. Association of Official Agricultural Chemists (AOAC). (2005) Official Methods of Analysis of AOAC International. 18th ed. Rockville, MD, USA.

4. Asimov I. (1974) Asimov on Chemistry. Doubleday: Garden City, NY, USA.

5. Borges SA, Fischer da Silva AV, Majorka A, Hooge DM, Cummings KR. (2004) Physiological responses of broiler chickens to heat stress and dietary electrolyte balance (sodium plus potassium minus chloride, milliequivalents per kilogram). Poult Sci. 83(9), 1551-1558. DOI: 10.1093/ ps/83.9.1551.

6. Conway RE, Geissler CA, Hider RC, Thompson RP, Powell JJ. (2006) Serum iron curves can be used to estimate dietary iron bioavailability in humans. Nutr J. 136(7), 1910-1914 DOI: 10.1093/jn/136.7.1910.

7. Daneshyar M, Kermanshahi H, Golian A. (2009) Changes of biochemical parameters and enzyme activities in broiler chickens withcold-induced ascites. Poult Sci. 88, 106. DOI: 10.3382/ps.2008-00170.

8. Dorman HJD, Dean SG. (2000) Antimicrobial agent from plants: antimicrobial activity of plant volatile oils. $J$ Appl. Microbiol. 88, 308-316. DOI: 10.1046/j.13652672.2000.00969.x.

9. González FHD. (2006) Introdução à Bioquímica Clínica Veterinária. 2aed. Porto Alegre: UFRGS, 360p.

10. International Committee for Standardization in Haematology (ICSH). (1978) The measurement of total and unsaturated iron binding capacity in serum. Br J Haematol. 38, 281290. DOİ: 10.1111/j.1365-2141.1978.tb01044.x.

11. Isolauri E, Sütas Y, Kankaanpaa P, Arvilommi H, Salminen S. (2001) Probiotics: Effects of immunity. Am. J. Clin. Nutr.73,444-450.DOI: 10.1093/ajcn/73.2.444s

12. Kefalı S, Toker NY. (2006) Effects of probiotics on some acute phase proteins in broilers exposed to Salmonella typhimurium lipopolysaccharides 1,2. Arch. Geflügelk. 70 (6), 270-277.

13. Khan WA, Khan A, Anjuman A, Rehman Z. (2002) Effects of induced heat stress on some biochemical values in broiler chicks. Int J Agric Biol. 4, 74-5.

14. Klasing KC. (1998) Comparative Avian Nutrition; CAB International: Wallingford, UK.

15. Kohne HJ, Jones JE. (1975) Changes in plasma electrolytes, acid-base balance and other physiological parameters of adult female turkeys under conditions of acute hyperthermia. Poult Sci.54, pp. 2034-2038. DOI: 10.3382/ ps.0542034

16. Lumeij JT. (1997) Avian clinical biochemistry. In: Kaneko JJ, Harvey JW, Bruss ML (eds) Clinical biochemistry of domestic animals, 5th edn. Academic Press, London, pp 857-883.

17. McCormick CC, Garlich JD, Edens FW. (1979) Fasting and diet affect the tolerance of young chickens exposed 
to heat stress. J. Nutr.109 , pp. 1797-1809. DOI: 10.1093/ jn/109.10.1797.

18. McCormick CC, Garlich JD, Edens FW. (1980) Phosphorus nutrition and fasting: interrelated factors which affect the survival of young chickens exposed to high ambient temperature. J. Nutr. 110 , pp. 837-850. DOI: 10.1093/ $\mathrm{jn} / 110.4 .784$.

19. Molero C. (2007) Nutritional solutions to heat stress. International Poultry Production. Volume 15, number 5, 27- 29.

20. Moraesa VMB, Malheirosb RD, Bruggemanb V, Collinc A, Tonab K, Van Asb P, Onagbesanb OM, Buyseb J, Decuypere E, Macaria M. (2003) Effect of Thermal Conditioning During Embryonic Development on Aspects of Physiological Responses of Broilers to Heat Stres. $J$ of Thermal Biol. 28(2),133-140.DOI: 10.1016/S03064565(02)00049-9.

21. Nelson TS. (1967) The Utilization of Phytate P by Poultry a review. Poult Sci.. 46: 862. DOI: 10.3382/ps.0460862.

22. NRC. (1984) Nutrient Requirements of Poultry. 8th Rev. ed. Natl. Acad. Press, Washington, DC.

23. Salvador D, Arıkı J, Borges SA, Pedroso AA, Moraes VMB. (1999) Suplementação de bicarbonato de sódio na ração e na água de bebida de frangos de corte submetidos ao estresse calórico. ARS Veterinária. 15,144-148.

24. Savica V, Calo LA, Monardo P, Santoro D, Bellinghieri G. (2012) Phosphate binders and management of hyperphosphataemia in end-stage renal disease. Nephrol Dial Transplant. 21(8),2065-2068.DOI: 10.1093/ndt/gfl289.
25. Smith MO, Teeter RG. (1987) Potassium balance of the 5 to 8 -week-old broiler exposed to constant heat or cycling high temperature stress and the effects of supplemental potassium chloride on body weight gain and feed efficiency. Poult Sci. 66(3), 487-492. DOI: 10.3382/ps.0660487.

26. Tekce E, Gül M. (2015) Sicaklık Stresi Altında Beslenen Etçi Piliçlerde Origanum Syriacum Uçucu Yağının performans Antioksidan Potansiyel Lipid Profili Bağırsak Mikroflorası ve Et Kalitesine Etkisi. Doktora Tezi, AÜ Sağlık Bilimleri Enstitüsü, Erzurum.

27. Vahl HA, Van T, Klooster AT. (1987) Dietary iron and broiler performance. Br Poult Sci. 28(4),567-576.DOI: 10.1080/00071668708416992.

28. Voyvoda H, Sekin S, Bildik A. (1992) Koyunlarda Dexamethason Uygulmasının Serum Demir, Total Demir Bağlama Kapasitesi, Transferrin Doyumu ve Bakır Düzeyine Etkisi. YYU Vet Fak Derg. 3(1), 197-208.

29. Botsoglou NA, Christaki E, Florou-Paneri P, Giannenas I, Papageorgiou G, Spais AB. (2004) The effect of a mixture of herbal essential oils or á-tocopheryl acetate on performance parameters and oxidation of body lipid in broilers. S Afr J Anim Sci. 34(1), 52-61.DOI: 10.4314/sajas. v34i1.4039.

30. Özek G, Demirci F, Özek T, Tabanca N, Wedge DE, Khan SI, Başer KHC, Duran A, Hamzaoglu E. (2010) Gas chromatographic-mass spectrometric analysis of volatiles obtained by four different techniques from Salvia rosifolia Sm., and evaluation for biological activity. J Chromatogr A.1217,741-748. DOI: 10.1016/j.chroma.2009.11.086. 